\title{
PENURUNAN LOGAM BERAT DAN PIGMEN PADA PENGOLAHAN Geluring RUMPUT LAUT Gelidium sp. DAN Ulva lactuca
}

\author{
Erniati $^{1,4)}$, Fransiska Rungkat Zakaria ${ }^{2 \star \star}$, Endang Prangdimurti ${ }^{2)}$, Dede Robiatul \\ Adawiyah $^{2)}$, Bambang Pontjo Priosoeryanto ${ }^{3)}$
}

1) Program Studi Ilmu Kelautan, Fakultas Pertanian Universitas Malikussaleh, Aceh

2) Departemen Ilmu dan Teknologi Pangan, Fakultas Teknologi Pertanian, Institut Pertanian Bogor, Jalan. Lingkar Akademik, 16680, Telepon (0251) 8621210, Faks. (0251) 8623203

3) Departemen Klinik Reproduksi dan Patologi Fakultas Kedokteran Hewan, Institut Pertanian Bogor,

4) Program Studi Ilmu Pangan, Sekolah Pascasarjana, Institut Pertanian Bogor, Bogor

* Korespondensi: since@apps.ipb.ac.id

Diterima: 31 Mei 2017/ Disetujui: 10 Juli 2018

Cara sitasi: Erniati, Zakaria FR, Prangdimurti E, Adawiyah DR, Priosoeryanto BP. 2018. Penurunan logam berat dan pigmen pada pengolahan geluring dari rumput laut Gelidium sp. dan Ulva lactuca. Jurnal Pengolahan Hasil Perikanan Indonesia. 21(2): 266-275.

\begin{abstract}
Abstrak
Rumput laut merupakan komoditi penting sebagai bahan pangan sehat. Geluring (produk tradisional yang menyerupai nori) adalah produk pangan berbentuk lembaran kering, tipis dan berwarna hijau kecoklatan, dibuat dari campuran rumput laut Gelidium sp. dan Ulva lactuca. Tujuan penelitian ini adalah menentukan pengaruh proses pengolahan geluring terhadap kadar klorofil, karotenoid dan logam berat. Tahapan proses pengolahan geluring terdiri dari perendaman rumput laut kering, pengecilan ukuran, penghalusan, pembuatan bubur, penambahan bumbu, pencetakan dan pemanggangan. Pembutaan produk geluring terdiri dari P1: geluring tanpa bumbu, P2: geluring berbumbu dan P3: geluring berbumbu dan dipanggang, analisis bahan baku juga dilakukan pada rumput laut Gelidium sp. segar (GS) dan kering (GK), U. lactuca segar (US) dan kering (UK). Analisis terdiri dari analisis kadar klorofil, karotenoid dan residu logam berat pada produk geluring. Hasil penelitian menunjukkan bahwa pengolahan geluring berpengaruh nyata $(\mathrm{P}<0,05)$ terhadap penurunan jumlah klorofil $a$, klorofil $b$, klrorofil total, karotenoid dan pengurangan residu logam berat. Kadar klorofil a, klorofil total dan karotenoid tertinggi terdapat pada geluring P1 dengan nilai $0,60 \mathrm{mg} / \mathrm{g}, 1,06 \mathrm{mg} / \mathrm{g}$ dan $0,23 \mathrm{mg} / \mathrm{g}$, sedangkan kadar klorofil b geluring P1 dan P2 mempunyai nilai yang sama $(0,46 \mathrm{mg} / \mathrm{g})$. Residu logam berat $\mathrm{Pb}$ dan $\mathrm{Cd}$ geluring $\mathrm{P} 1, \mathrm{P} 2$ dan $\mathrm{P} 3$ yaitu $\mathrm{Pb}<0,001 \mathrm{mg} / \mathrm{kg}$ dan $\mathrm{Cd}<0,02 \mathrm{mg} / \mathrm{kg}$. Nilai ini jauh lebih rendah dibandingkan residu $\mathrm{Pb}$ dan $\mathrm{Cd}$ pada bahan baku U. lactuca kering dan Gelidium sp. kering yaitu pada kisaran 1,18-5,71 mg/kg. Proses pengolahan geluring mengurangi kadar klorofil dan karotenoid, akan tetapi bermanfaat untuk menurunkan residu logam berat pada produk olahan rumput laut.
\end{abstract}

Kata kunci : Cd, klorofil, $\mathrm{Pb}$, pengeringan, produk lembaran kering

\section{Decreasing Heavy Metals and Pigments in Processing of Geluring from Gelidium sp. and Ulva lactuca Seaweeds}

\begin{abstract}
Seaweed is an important commodity as a healthy food. Geluring (a nori-like product) represents a thin, dry and brownish-green food product made from mixture of Gelidium sp. and Ulva lactuca seaweeds. The aims of this research was to determine effect of geluring process on the chlorophyll, carotenoid and heavy metal residue. Analysis consisted of chlorophyll, carotenoid and heavy metal residue content of the geluring product. The stages of the geluring process consisted of dry seaweed immersion, size reduction, pulping, seasoning, molding and roasting. The geluring that was made and analyzed consisted of P1: unseasoned geluring, P2: seasoned geluring and P3: seasoned and roasted geluring. The raw materials were analysed both fresh (GS) and dried (GK) Gelidium sp., as well as fresh (US) and dried (UK) U. lactuca. The result showed that geluring processing significantly affected $(\mathrm{P}<0.05)$ the chlorophyll a, total chlorophyll, carotenoid pigment and heavy metal residue. The highest of chlorophyll a, total chlorophyll and carotenoid content was the P1 geluring with values of chlorophyll a $0.60 \mathrm{mg} / \mathrm{g}$, total chlorophyll $1.06 \mathrm{mg} / \mathrm{g}$ and carotenoid 0.23 $\mathrm{mg} / \mathrm{g}$. Chlorophyll b content of P1 and P2 geluring had the same value $(0.46 \mathrm{mg} / \mathrm{g})$. The heavy metal residues
\end{abstract}


of $\mathrm{Pb}$ and $\mathrm{Cd}$ in the $\mathrm{P} 1, \mathrm{P} 2$ and $\mathrm{P} 3$ geluring were $\mathrm{Pb}<0.001 \mathrm{mg} / \mathrm{kg}$ and $\mathrm{Cd}<0.02 \mathrm{mg} / \mathrm{kg}$. This value was lower than $\mathrm{Pb}$ and $\mathrm{Cd}$ contents in the raw materials of dried U. lactuca and Gelidium sp ranging of 1.18-5.71 mg/ $\mathrm{kg}$. The geluring processing reduced the levels of chlorophyll and carotenoids, but it also reduced heavy metals in the seaweed products.

Keywords: Carotenoids, Cd, chlorophyll, dry sheet product, $\mathrm{Pb}$

\section{PENDAHULUAN}

Rumput laut merupakan kekayaan hayati laut yang banyak tersebar di perairan Indonesia, baik tumbuh secara alami maupun hasil budidaya. Rumput laut telah lama dimanfaatkan oleh masyarakat sebagai obat, bahan pangan maupun kosmetik. Rumput laut Indonesia telah diteliti mengandung antioksidan yang tinggi dalam menangkal radikal bebas (Firdaus 2003; Diachanty et al. 2017; Nufus et al. 2017; Gazali et al. 2018) dan dapat meningkatkan sistem imun (Subaryono et al. 2017). Komoditi rumput laut telah diteliti mengandung komponen bioaktif di antaranya fenol (Machu et al. 2015; Zakaria et al. 2017), flavonoid (Elmegeed et al. 2014), klorofil dan karotenoid (Rohani-Ghadikolaei et al. 2012; Pangestuti dan Kim 2011) dan polisakarida sulfat (Barahona et al. 2014).

Klorofil dan karotenoid merupakan pigmen alami yang tersebar pada semua jenis rumput laut baik Phaeophyceae, Rhodophyceae dan Chlorophyceae dengan komposisi yang bervariasi (Chen et al. 2017; Bocanegara et al. 2009; Holdt dan Kraan 2011). Rumput laut hijau (Chlorophyceae) merupakan jenis rumput laut yang memiliki kandungan klorofil paling tinggi (Haryatfrehni et al. 2015). Pigmen karotenoid terutama terdapat pada jenis rumput laut cokelat dan rumput laut merah (Holdt dan Kraan 2011). Pigmen klorofil dan karotenoid telah diteliti mempunyai efek biologis untuk meningkatkan kesehatan, di antaranya antioksidan, antiinflamasi maupun antikanker (Pangestuti dan Kim 2011; Prangdimurti et al. 2006).

Rumput laut dapat diolah menjadi bermacam produk pangan dengan melibatkan berbagai metode pengolahan, tetapi yang sering menjadi kendala adalah kandungan logam berat. Kontaminan logam berat di perairan umumnya dihasilkan oleh aktivitas industri dan aktivitas pelayaran industri, transportasi, maupun kapal nelayan (Cahyani et al. 2016). Rumput laut termasuk jenis organisme laut yang dapat menyerap dan mengakumulasi logam berat yang terdapat di lingkungan perairan (Yong et al. 2017; Nufus et al. 2017; Cadar et al. 2016; Besada et al. 2009), hal ini tentu akan membahayakan jika rumput laut yang mengandung logam berat dikonsumsi oleh manusia, oleh sebab itu perlu dikembangkan teknik pengolahan produk pangan yang dapat menghilangkan kandungan logam berat pada rumput laut.

Produk pangan yang diolah dari rumput laut salah satunya adalah produk lembaran kering misalnya nori. Nori merupakan produk berupa lembaran tipis dan kering, berwarna hijau kehitaman yang sering dikonsumsi oleh masyarakat Jepang, Cina atau Korea dan dibuat dari rumput laut jenis Porphyra sp. (Taboada et al. 2012). Porphyra sp. adalah jenis rumput laut yang tidak umum tumbuh di perairan tropis seperti di Indonesia, oleh sebab itu penelitian ini mencoba mengembangkan produk lembaran kering yang disebut dengan geluring, dibuat dari campuran rumput laut lokal Indonesia di antaranya dari campuran Gelidium sp. dan U. lactuca. Kedua jenis rumput laut ini tumbuh secara alami dan dikonsumsi oleh masyarakat (Nurjanah et al. 2018). Penggunaan dua jenis rumput laut pada pembuatan produk geluring bertujuan untuk mendapatkan bentuk lembaran kering dengan tekstur yang dapat diterima. Gelidium sp. merupakan jenis rumput laut merah yang mengandung agar (Ashoush et al. 2017), dapat berfungsi sebagai pembentuk gel sehingga memudahkan membentuk lembaran, sedangkan penambahan $U$. lactuca dapat memberikan tekstur renyah, meningkatkan warna dan menambah kandungan serat dan komponen bioaktif produk, di antaranya meningkatkan 
kandungan klorofil produk geluring. Ulva lactuca merupakan salah satu jenis rumput laut hijau yang banyak mengandung klorofil (El-Baky et al. 2008; Chakraborty dan Santra 2008).

Proses pengolahan geluring meliputi perendaman dengan asam, pembuatan bubur dan pengeringan lembaran dengan melibatkan panas diperkirakan dapat memengaruhi kandungan pigmen klorofil dan karotenoid, akan tetapi diharapkan proses ini dapat menurunkan residu logam berat. Klorofil dan karotenoid mempunyai kelemahan, yaitu kurang stabil terhadap perlakuan panas, cahaya ataupun asam (Benlloch-Tinoco et al. 2015; Arnold et al. 2014). Klorofil dapat berubah menjadi feofitin, pirofeofitin dan feoforbid pada pengolahan pangan yang melibatkan panas dan asam (Kang et al. 2018). Cahaya, panas dan asam juga akan memengaruhi ikatan rangkap pada karotenoid. Pigmen karotenoid lebih stabil terhadap suhu, asam dan cahaya dibandingkan pigmen klorofil (Benlloch-Tinoco et al. 2015; Cervantes-Paz et al. 2014). Berbagai proses pemasakan seperti penguapan, microwave dan perebusan sayuran dilaporkan dapat menghilangkan kandungan klorofil a dan klorofil b dengan kisaran 9-81\% tergantung jenis sayuran dan metode pemasakan (Turkmen et al. 2006). Metode dan suhu pengeringan berpengaruh terhadap komposisi dan kadar pigmen klorofil dan karotenoid (Naidu et al. 2016; Yang et al. 2009). Hasil penelitian Prangdimurti et al. (2005) dan Cervantes-Paz et al. (2014) melaporkan bahwa perubahan kimia khlorofil menjadi senyawa turunannya tetap memberikan aktivitas antioksidan.

Penelitian ini bertujuan untuk menentukan pengaruh proses pengolahan geluring terhadap kadar klorofil, karotenoid dan logam berat. Penelitian ini diharapkan dapat memberikan informasi ilmiah kepada masyarakat tentang kadar klorofil dan karotenoid produk pangan berbentuk lembaran kering berbahan baku rumput laut serta dapat memberikan cara alternatif untuk menghilangkan kandungan logam berat pada produk olahan rumput laut.

\section{BAHAN DAN METODE Bahan dan Alat}

Bahan utama dalam penelitian ini terdiri dari rumput laut Gelidium sp. dan Ulva lactuca dalam kondisi segar (baru dipanen) dan kondisi kering dengan dijemur matahari, diperoleh dari petani pengumpul rumput laut di pantai Sayang Heulang Kecamatan Pameungpeuk, Garut, Jawa Barat. Bahan lain untuk membuat produk geluring adalah asam cuka teknis $2 \%$, bawang putih bubuk, lada bubuk dan garam diperoleh dari toko penjual rempah dan bahan dapur. Bahan kimia untuk analisis yang digunakan terdiri dari aseton 85\% (Merck), asam nitrat p.a (Merck) dan asam perklorat p.a (Merck).

Alat yang digunakan terdiri dari blender (Philips HR 2116), oven pengering (Cascade Tex, USA), oven pemanggang (Sanyo SK-8600 FM, Jepang), spektrofotometer UV (Shimadzu UV-1800, USA), spektrofotometer serapan atom (SSA) ( PG-990, UK), kompor rinnai dan peralatan gelas (pyrex).

\section{Metode Penelitian Penyiapan sampel}

Rumput laut segar yang baru dipanen, dicuci bersih dengan air laut, kemudian dicuci dengan air tawar, selanjutnya ditiriskan dan dikemas dalam kantong plastik dan disimpan dalam refrigerator sampai waktu analisis dilakukan. Sampel rumput laut kering merupakan rumput laut yang dikeringkan oleh petani rumput laut dengan sinar matahari selama 3-4 hari hingga mencapai kadar air $10-13 \%$.

\section{Pembuatan produk Geluring}

Pembuatan produk geluring dilakukan berdasarkan modifikasi metode Zakaria et al. (2017). Rumput laut kering Gelidium sp. dicuci bersih dan direndam dengan air (perbandingan 1:2) selama 24 jam sedangkan $U$. lactuca direndam selama 6 jam. Rumput laut ditiriskan dan selanjutnya direndam dengan cuka $2 \%$ selama 30 menit, kemudian dicuci dan ditiriskan, rumput laut dipotong kecil dan diblender dengan air (perbandingan 1:1) sehingga diperoleh hancuran rumput laut. Tahapan berikutnya adalah pembuatan bubur, 
bubur U. lactuca dibuat dengan cara menambahkan air kedalam hancuran rumput laut (perbandingan 1:1) kemudian dimasak pada suhu $90-100^{\circ} \mathrm{C}$ selama 30 menit. Bubur Gelidium sp. dibuat dengan cara yang sama, akan tetapi dengan perbandingan air 1:9 dan dimasak selama 2 jam. Terdapat tiga produk geluring yang dibuat, yaitu P1: geluring tanpa bumbu dibuat dengan mencampurkan bubur Gelidium sp. dan bubur U. lactuca (perbandingan 3:1), dicetak tipis pada loyang teflon dengan menuangkan campuran bubur sebanyak $0,3 \mathrm{~g} / \mathrm{cm}^{2}$ luas area cetakan kemudian dikeringkan pada suhu $50^{\circ} \mathrm{C}$ selama 2 jam. P2: dengan penambahan $0,1 \%$ garam, $0,1 \%$ bawang putih bubuk dan $0,1 \%$ lada bubuk, serta P3: geluring berbumbu dengan metode yang sama dengan pembuatan P2 dan dipanggang, akan tetapi setelah membentuk lembaran kering diolesi dengan minyak kelapa dan dipanggang pada suhu $100^{\circ} \mathrm{C}$ selama 2 menit. Lembaran geluring P1, P2 and P3 dikemas vakum sampai digunakan untuk analisis.

\section{Analisis kadar klorofil dan karotenoid}

Analisis kadar klorofil dilakukan terhadap sampel rumput laut Gelidium sp. segar (GS), Gelidium sp. kering (GK), U. lactuca segar (US), U. lactuca kering (UK), produk geluring (P1), (P2) dan (P3). Analisis klorofil dan karotenoid mengacu metode Sims dan Gamon (2002). Sampel sebanyak 0,01 gram ditimbang dan dihaluskan dengan $1 \mathrm{~mL}$ larutan aseton/ buffer tris (80:20), kemudian ditambah larutan aseton/buffer tris sampai volume akhir $5 \mathrm{~mL}$. Campuran selanjutnya disentrifuse pada $4.500 \mathrm{rpm}$ selama 5 menit. Absorbansi larutan dibaca dengan spektrofotometer UV, kadar klorofil dan karotenoid ditentukan melalui perhitungan A. Berat molekul per mol klorofil a adalah $893,5 \mathrm{~g} / \mathrm{mol}$, klorofil b $907,5 \mathrm{~g} / \mathrm{mol}$ dan total karotenoid $550 \mathrm{~g} / \mathrm{mol}$ digunakan untuk mengkonversi kadar klorofil dan karotenoid menjadi g/mL. Kadar klorofil per gram sampel dapat dihitung melalui perhitungan $B$.

\section{Analisis residu logam berat}

Analisis residu logam berat dilakukan menggunakan spektrofotometer serapan atom (SSA) mengacu pada metode Rice et al. (2012). Sampel serbuk sebanyak 2,5 gram terlebih dahulu didestruksi dengan asam nitrat (p.a) selama semalam kemudian dipanaskan pada suhu $100^{\circ} \mathrm{C}$ selama 1 jam 30 menit, didinginkan dan ditambah lagi $5 \mathrm{~mL}$ asam nitrat (p.a) dan $1 \mathrm{~mL}$ asam perklorat (p.a), dipanaskan kembali $130^{\circ} \mathrm{C}$ selama 1 jam. suhu ditingkatkan menjadi $150^{\circ} \mathrm{C}$ selama 2 jam 30 menit (sampai uap kuning habis, bila masih ada uap kuning waktu pemanasan ditambah lagi). Suhu ditingkatkan kembali apabila uap kuning telah habis menjadi $170^{\circ} \mathrm{C}$ selama 1 jam, kemudian ditingkatkan lagi menjadi $200^{\circ} \mathrm{C}$ selama 1 jam (hingga terbentuk uap putih). Destruksi selesai dengan terbentuknya endapan putih atau sisa larutan jernih sekitar $1 \mathrm{~mL}$. Larutan jernih didinginkan, diencerkan dengan air bebas ion menjadi $25 \mathrm{~mL}$, lalu dikocok, dihomogenkan dan dibiarkan semalam. Ekstrak jernih ini digunakan untuk pengukuran logam berat $\mathrm{Pb}$ dan Cd menggunakan SSA metode nyala pada panjang gelombang masing-masing $283,3 \mathrm{~nm}$ untuk analisis $\mathrm{Pb}$ dan 228,2 untuk analisis $\mathrm{Cd}$. Konsentrasi logam berat $\mathrm{Pb}$ dan $\mathrm{Cd}$ dihitung menggunakan kurva standar.

\section{Perhitungan A}

Klorofil a $(\mu \mathrm{mol} / \mathrm{mL}) \quad=0,01373 \mathrm{~A}_{663}-0,000897 \mathrm{~A}_{537}-0,003046 \mathrm{~A}_{647}$

Klorofil b $(\mu \mathrm{mol} / \mathrm{mL}) \quad=0,02405 \mathrm{~A}_{647}-0,004305 \mathrm{~A}_{537}-0,005507 \mathrm{~A}_{663}$

Total Klorofil $(\mu \mathrm{mol} / \mathrm{mL})=$ Klorofil A + Klorofil B

Karotenoid $(\mu \mathrm{mol} / \mathrm{mL})$

$\mathrm{A}_{470^{-}}(17,1 \times$ total klorofil $)$

\section{Perhitungan B}

Kadar klorofil atau karotenoid $(\mathrm{mg} / \mathrm{g})=$ $\frac{\text { kadar klorofil }\left(\frac{g}{m L}\right) \times \text { volume ekstrak }}{\text { berat sampel kering }}$ 


\section{Analisis Data}

Rancangan penelitian yang digunakan adalah rancangan acak lengkap (RAL), terdiri dari 7 sampel dan 3 kali ulangan, yaitu: P1 (geluring tanpa bumbu), P2 (geluring berbumbu), P3 (geluring berbumbu dan dipanggang), GK (Gelidium kering), GS (Gelidium segar), UK (U. lactuca kering) dan US (U. lactuca segar). Data yang diperoleh dianalisis dengan Analysis of Varians (ANOVA), dilanjutkan dengan uji Duncan pada taraf nyata 5\%. Pengolahan data menggunakan program SPSS.

\section{HASIL DAN PEMBAHASAN Kandungan Klorofil dan Karotenoid Produk Geluring}

Hasil penelitian menunjukkan bahwa proses pengolahan geluring berpengaruh nyata $(\mathrm{P}<0,05)$ terhadap kandungan klorofil a, klorofil b, klorofil total dan karotenoid dibandingkan rumput laut segar dan rumput laut kering. Kandungan klorofil a, klorofil b, klorofil total dan karotenoid geluring P1 berbeda nyata $(\mathrm{P}<0,05)$ dengan geluring $\mathrm{P} 3$ (Tabel 1). Geluring P3 memiliki kandungan klorofila,klorofilb,klorofil totaldan karotenoid yang lebih rendah, hal ini kemungkinan karena pada proses roasting (pemanggangan) pada suhu $100^{\circ} \mathrm{C}$ dapat menghilangkan sebagian besar klorofil yang dimiliki. Pumilia et al. (2014) menyatakan bahwa selama proses pemanggangan pada suhu tinggi, klorofil akan lebih cepat terdegradasi menjadi senyawa turunannya misalnya feofitin yang lebih stabil. Kandungan karotenoid pada geluring P3 menurun, namun tidak sebesar penurunan pigmen klorofil karena pigmen karotenoid pada produk geluring lebih stabil terhadap suhu tinggi dibandingkan pigmen klorofil, hal ini sesuai dengan pernyataan Cervantes-Paz et al. (2014) yang menyatakan bahwa pigmen karotenoid lebih stabil terhadap suhu dan cahaya dibandingkan pigmen klorofil.

Berdasarkan datapada Tabel 1, kandungan klorofil a, klorofil b, klorofil total dan karotenoid produk geluring (P1, P2, P3) mengalami penurunan nilai yang signifikan $(\mathrm{P}<0,05)$ dibandingkan dengan rumput laut segar (GS dan US) dan juga dengan rumput laut kering (GK dan UK). Bahan baku rumput laut segar juga memiliki kadar klorofil dan karotenoid yang berbeda nyata $(\mathrm{P}<0,05)$ dengan rumpu laut kering. Proses pengeringan secara konvensional menggunakan cahaya matahari umum dilakukan oleh petani pengumpul rumput laut dapat menurunkan kadar klorofil a, klorofil b, klorofil total dan kadar karotenoid. Penurunan kadar klorofil a U. lactuca sekitar 41\% dan pada Gelidium 28\%. Penurunan kadar klorofil b pada U. lactuca dan Gelidium sp. yaitu 22\%. Hasil ini menunjukkan bahwa klorofil a pada Gelidium sp. dan U. lactuca lebih mudah terdegradasi dibandingkan klorofil b. Data ini didukung oleh pernyataan Turkmen et al. (2006) bahwa klorofil a lebih mudah terdegradasi menjadi feofitin

Tabel 1 Kandungan klorofil a, klorofil b, klorofil total dan karotenoid produk geluring

(Table 1 Chlorophyll a, chlorophyll b, total chlorophyll and carotenoid content of geluring product)

\begin{tabular}{ccccc}
\hline Sampel/sample & $\begin{array}{c}\text { Klorofil a/ } \\
\text { chlorophyll a } \\
(\mathrm{mg} / \mathrm{g})\end{array}$ & $\begin{array}{c}\text { Klorofil b/ } \\
\text { chlorophyll b } \\
(\mathrm{mg} / \mathrm{g})\end{array}$ & $\begin{array}{c}\text { Klorofil total/ } \\
\text { total chlorophyll } \\
(\mathrm{mg} / \mathrm{g})\end{array}$ & $\begin{array}{c}\text { Karotenoid/ } \\
\text { carotenoid } \\
(\mathrm{mg} / \mathrm{g})\end{array}$ \\
\hline P1 & $0.62 \pm 0.03^{\mathrm{b}}$ & $0.46 \pm 0.04^{\mathrm{a}}$ & $1.07 \pm 0.07^{\mathrm{b}}$ & $0.24 \pm 0.02^{\mathrm{a}}$ \\
P2 & $0.60 \pm 0.03^{\mathrm{b}}$ & $0.46 \pm 0.03^{\mathrm{a}}$ & $1.06 \pm 0.03^{\mathrm{b}}$ & $0.23 \pm 0.01^{\mathrm{a}}$ \\
P3 & $0.45 \pm 0.03^{\mathrm{a}}$ & $0.44 \pm 0.01^{\mathrm{ab}}$ & $0.89 \pm 0.03^{\mathrm{a}}$ & $0.21 \pm 0.01^{\mathrm{ab}}$ \\
GK & $0.76 \pm 0.03^{\mathrm{c}}$ & $0.67 \pm 0.01^{\mathrm{b}}$ & $1.42 \pm 0.02^{\mathrm{c}}$ & $0.31 \pm 0.02^{\mathrm{c}}$ \\
GS & $1.05 \pm 0.02^{\mathrm{e}}$ & $0.86 \pm 0.01^{\mathrm{d}}$ & $1.91 \pm 0.02^{\mathrm{e}}$ & $0.39 \pm 0.04^{\mathrm{d}}$ \\
UK & $0.88 \pm 0.07^{\mathrm{d}}$ & $0.79 \pm 0.04^{\mathrm{c}}$ & $1.67 \pm 0.11^{\mathrm{d}}$ & $0.28 \pm 0.04^{\mathrm{bc}}$ \\
US & $1.48 \pm 0.03^{\mathrm{f}}$ & $1.01 \pm 0.02^{\mathrm{e}}$ & $2.49 \pm 0.03^{\mathrm{f}}$ & $0.36 \pm 0.02^{\mathrm{d}}$ \\
\hline
\end{tabular}


dibandingkan klorofil b pada berbagai sayuran karena proses pemanasan.

Penurunan kadar klorofil dan karotenoid pada U. lactuca dan Gelidium sp. nilainya berbeda, karena perbedaan jenis rumput laut, sehingga memiliki karakteristik fisik dan kimia yang berbeda. Gelidium sp. merupakan jenis rumput laut merah dan secara morfologi memiliki karakteristik fisiologi jaringan yang lebih keras dibandingkan $U$. lactuca, sehingga proses degradasi komponen kimia, termasuk klorofil dan karotenoid lebih lama. Kandungan klorofil dan karotenoid rumput laut sangat bervariasi, tergantung jenis rumput laut, perbedaan musim, kondisi lingkungan perairan dan penanganan pasca panen (Holdt dan Kraan 2011).

Berdasarkan data kandungan klorofil dan karotenoid bahan baku rumput laut, dapat disimpulkan bahwa kehilangan klorofil pada pembuatan geluring tidak mutlak terjadi karena proses pengolahan, akan tetapi juga karena proses pengeringan bahan baku. Hal ini didapat dari hasil pembuatan geluring menggunakan bahan baku rumput laut kering.

Proses pembuatan geluring (P1, P2, P3), meliputi pemasakan bubur dan pengeringan lembaran menggunakan oven pada suhu $50^{\circ} \mathrm{C}$ menyebabkan klorofil terdegradasi menjadi produk turunannya di antaranya senyawa feofitin, serta perendaman dengan asam mempercepat degradasi tersebut. Hal ini didukung oleh data produk geluring yang berwarna hijau kecoklatan. Feofitin merupakan senyawa turunan klorofil yang dapat memberikan warna hijau kecokelatan atau hijau-orange pada buah atau sayur yang mengalami penyimpanan atau pengolahan (Charoenchongsuk et al. 2015). Ramirez et al. (2015) menyatakan bahwa adanya asam dan panas menyebabkan klorofil mengalami reaksi feofitinasi yang lebih cepat yaitu reaksi pembentukan senyawa feofitin melalui substitusi ion $\mathrm{Mg}^{2+}$ oleh ion hidrogen. Proses pemanasan pada pembuatan geluring mempercepat reaksi feofitinasi, karena panas dapat mendenaturasi protein. Klorofil umumnya berikatan dengan molekul protein pada matriks rumput laut (Barrett dan Anderson 1980). Rumput laut yang dipanaskan maka protein yang mengikat klorofil akan terdenaturasi menyebabkan klorofil berada dalam bentuk bebas, dalam kondisi ini klorofil tidakstabil dan akan mudah diserang oleh asam, sehingga $\mathrm{Mg}^{2+}$ di dalam molekul klorofil akan mudah digantikan oleh ion hidrogen (Aryanti et al. 2017).

Proses pengolahan geluring pada penelitian ini juga menurunkan kadar pigmen karotenid. Pemanasan dapat menghilangkan lebih dari 50\% kandungan karotenoid dan lebih dari 90\% kandungan klorofil (Benlloch-Tinoco et al. 2015; Lefsrud et al. 2008). Cahaya, panas dan asam mempengaruhi ikatan rangkap dari karotenoid sehingga akan mengubah struktur karotenoid dari isomer trans menjadi cis (Melendez-Martínez et al. 2010), namun pigmen karotenoid lebih stabil terhadap suhu, asam dan cahaya dibandingkan pigmen klorofil (Kailola et al. 2012).

\section{Residu Logam Berat}

Rumput laut merupakan organisme laut yang dapat menyerap dan mengakumulasikan logam berat dari lingkungan perairan (Nufus et al. 2017). Proses pengolahan rumput laut menjadi produk pangan tertentu diharapkan dapat mengurangi bahkan menghilangkan residu logam logam berat. Hasil penelitian menunjukkan bahwa proses pengolahan produk geluring dari rumput laut dapat menurunkan residu logam berat. Residu logam berat $\mathrm{Pb}$ dan $\mathrm{Cd}$ produk geluring, rumput laut kering Gelidium sp. (GK) dan U. lactuca (UK) hasil penelitian disajikan pada Tabel 2.

Berdasarkan Tabel 2, terlihat bahwa proses produk geluring secara deskriptif mengandung residu logam berat yang lebih rendah dibandingkan bahan baku rumput laut Gelidium sp. kering dan U. lactuca kering. Kedua jenis rumput laut kering yang digunakan mengandung residu logam berat melebihibatas maksimal persyaratan mutu dan keamanan rumput laut kering yang ditetapkan oleh BSN (2015), kandungan cemaran logam berat maksimal $0,3 \mathrm{mg} / \mathrm{kg}$ untuk $\mathrm{Pb}$ dan 0,1 $\mathrm{mg} / \mathrm{kg}$ untuk $\mathrm{Cd}$. Residu $\mathrm{Pb}$ dan $\mathrm{Cd}$ pada rumput laut kering Gelidium sp. dan U. lactuca yang tinggi menunjukkan bahwa proses pengeringan rumput laut dengan cahaya 
Tabel 2 Residu logam berat $\mathrm{Pb}$ dan $\mathrm{Cd}$ produk geluring dan rumput laut kering Gelidium sp. (GK) dan Ulva lactuca (UK)

(Table 2 The heavy metal content of $\mathrm{Pb}$ and $\mathrm{Cd}$ from geluring product and Gelidium sp. (GK) and Ulva lactuca (UK) dried seaweed)

\begin{tabular}{ccc}
\hline $\begin{array}{c}\text { Jenis sampel } \\
\text { Sample }\end{array}$ & $\begin{array}{c}\text { Residu } \mathrm{Pb} / \\
\mathrm{Pb} \text { content }(\mathrm{mg} / \mathrm{kg})\end{array}$ & $\begin{array}{c}\text { Residu Cd} / \\
C d \text { content }(\mathrm{mg} / \mathrm{kg})\end{array}$ \\
\hline $\mathrm{P} 1$ & $<0.001$ & $<0.02$ \\
$\mathrm{P} 2$ & $<0.001$ & $<0.02$ \\
$\mathrm{P} 3$ & $<0.001$ & $<0.02$ \\
$\mathrm{GK}$ & $5.18 \pm 0.8$ & $1.67 \pm 0.5$ \\
$\mathrm{UK}$ & $5.71 \pm 0.6$ & $1.18 \pm 0.7$ \\
\hline
\end{tabular}

matahari tidak dapat mengurangi residu $\mathrm{Pb}$ dan $\mathrm{Cd} . \mathrm{Pb}$ dan $\mathrm{Cd}$ pada rumput laut terikat oleh senyawa organik seperti protein atau polisakarida (Dadolahi-Sohrab et al. 2011; He dan Chen 2014). Pengeringan dengan cahaya matahari tidak dapat merubah struktur polisakarida atau protein dari rumput laut, sehingga kadarnya tidak berkurang (Yulianto et al. 2006).

Kandungan logam berat produk geluring P1, P2 dan P3 memenuhi persyaratan yang disyaratkan SNI tentang kadar logam berat $\mathrm{Pb}$ dan Cd pada rumput laut kering. Penurunan kadar logam berat pada produk geluring diduga disebabkan oleh proses pengolahan geluring yang terdiri dari perendaman dengan asam, pemasakan bubur dan pengeringan lembaran. Proses perendaman dengan asam dan dilanjutkan dengan proses pemanasan pada suhu sekitar $100^{\circ} \mathrm{C}$ ketika pembuatan bubur dapat menyebabkan protein atau polisakarida terhidrolisis, sehingga logam berat yang terikat pada senyawa tersebut akan lebih mudah terurai. Logam $\mathrm{Pb}$ atau Cd yang berikatan dengan polisakarida, pada pemanasan dengan suhu tinggi akan terlepas ikatannya (He dan Chen 2014), dan dalam bentuk kation ${ }^{2+}$ akan berikatan dengan asam menghasilkan garam dengan melepas ion $\mathrm{H}^{2+}$ (Dadolahi-Sohrab et al. 2011), garam tersebut kemungkinan larut pada proses pencucian setelah perendaman dengan asam dan menguap pada proses pemasakan bubur. Ghirisan et al. (2007) menyatakan bahwa logam berat dapat bereaksi dengan asam membentuk ion monovalen, bivalen atau trivalent. Nurjannah et al. (2018) melaporkan bahwa pembuatan garam rumput laut yang meliputi penghalusan ukuran dengan blender, pemasakan dengan suhu sampai $70^{\circ} \mathrm{C}$ dan pengeringan pada suhu $60^{\circ} \mathrm{C}$ selama 24 jam juga dapat mengurangi residu logam berat $\mathrm{Pb}$ pada garam rumput laut $U$. lactuca.

\section{KESIMPULAN}

Proses pengolahan geluring mengurangi kadar klorofil dan karotenoid, akan tetapi bermanfaat menurunkan residu logam berat. Pengurangan kadar klorofil a lebih tinggi dibandingkan klorofil $b$ dan penurunan kadar karotenoid lebih rendah dibandingkan klorofil. Penurunan kandungan klorofil dan karotenoid pada produk geluring masih memberikan warna hijau kecoklatan pada produk.

\section{DAFTAR PUSTAKA}

Arnold C, Schwarzenbolz U, Böhm V. 2014. Carotenoids and chlorophylls in processed xanthophyll-rich food. LWT-Food Science and Technology. 57(1): 442-445.

Aryanti N, Nafiunisa A. 2017. Extraction characteristic and degradation of chlorophyll from suji leaves (Pleomele angustifolia). Oriental Journal of Chemistry. 33(6): 3185-3190.

Ashoush YA, El-Sayed SM, Farid HE, AbdElwahab MA. 2017. Biochemical studies on red algae Gelidium sp. Grown in Egypt. Chemistry Research Journal. (5): 334-341.

Barahona T, Encinas MV, Imarai M, Mansilla A, Matsuhiro B,Torres R, Valenzuela B. 2014. Bioactive polysaccharides from marine algae. Journal Bioactive Carbohydrate and Dietary Fibre. 
4: $125-138$.

Barrett J,Anderson JM. 1980. The P-700chlorophyl a-protein complex and two major light-harvesting complexes of Acrocarpia paniculata and other brown seaweeds. Biochimica et Biophysica Acta (BBA)-Bioenergetics. 590(3): 309-323.

Benlloch-Tinoco M, Kaulmann A, CorteReal J, Rodrigo D, Martínez-Navarrete N, Bohn T. 2015. Chlorophylls and carotenoids of kiwifruit puree are affected similarly or less by microwave than by conventional heat processing and storage. Food Chemistry. 187: 254-262.

Besada V, Andrade JM, Schultze F, González JJ. 2009. Heavy metals in edible seaweeds commercialised for human consumption. Journal of Marine Systems. 75(1-2): 305-313.

Bocanegara A, Bastida S, Benedi J, Rodenas S, Sanchez-Muniz FJ. 2009. Characteristics and nutritional and cardiovascular-health properties of seaweeds. Journal Medicine Food. 12(2): 236-258.

[BSN] Badan Standardisasi Nasional. 2015. Rumput Laut Kering. SNI-2690. Jakarta (ID): Badan Standardisasi Nasional.

Cadar E, Pirjol TN, Tomescu A, Paris S, Erimia CL, Bogdan NS. 2016. Heavy metals existing in the seaweed from the Romanian Coast of the black sea. European Journal of Interdisciplinary Studies. 4(1): 92-99.

Cahyani N, Lumban Batu DTF, Sulistiono. 2016. Kandungan logam berat $\mathrm{Pb}, \mathrm{Hg}$, $\mathrm{Cd}$, dan $\mathrm{Cu}$ pada daging ikan rejung (Sillago sihama) di estuari Sungai Donan, Cilacap, Jawa Tengah. Jurnal Pengolahan Hasil Perikanan Indonesia. 19(3): 267-276.

Chakraborty S, Santra SC. 2008. Biochemical composition of eight benthic algae collected from Sunderban. Indian Journal Marine Science. 37: 329-332.

Charoenchongsuk N, Ikeda K, Itai A, Oikawa A, Murayama H. 2015. Comparison of the expression of chlorophyll-degradationrelatedgenes during ripening between stay-green and yellow-pear cultivars. Scientia Horticulturae. 181: 89-94.

Cervantes-Paz B, Yahia EM, de Jesus
Ornelas-Paz J, Victoria-Campos CI, Ibarra- Junquera V, Péeez-Martínez JD. 2014. Antioxidant activity and content of chlorophylls and carotenoids in raw and heat-processed Jalapeno peppers at intermediate stages of ripening. Food Chemistry. 146: 188-196.

Chen K, Ríos JJ, Perez-Galvez A, Roca, M. 2017. Comprehensive chlorophyll composition in the main edible seaweeds. Food Chemistry. 228: 625-633.

Dadolahi-Sohrab A, Nikvarz A, Nabavi SMB, Safahyeh A, Ketal-Mohseni, M. 2011. Environmental monitoring of heavy metals in seaweed and associated sediment from the Strait of Hormuz, IR Iran. World Journal of Fish and Marine Sciences. 3(6): 576-589.

Diachanty S, Nurjanah, Abdullah A. 2017. Aktivitas antioksidan berbagai jenis rumput laut coklat dari Perairan Kepulauan Seribu. Jurnal Pengolahan Hasil Perikanan Indonesia. 20(2): 305-318.

El-Baky HA, El Baz FK, El-Baroty GS. 2008. Evaluation of marine alga Ulva lactucaas a source of natural preservative ingredient. Am-Euras Journal Agriculture Enviromental Sciences. 7(11): 3353-3367.

Elmegeed DFA, Ghareeb DA, Elsayed M, El-Saadani M. 2014. Phytochemical constituents and bioscreening activities of green algae Ulva lactuca. International Journal of Agricultural Policy and Research. 2(11): 373-378.

Firdaus M. 2003. Indek aktivitas antioksidan ekstrak rumput laut coklat (Sargassum aquifolium). Jurnal Pengolahan Hasil Perikanan Indonesia. 16(1): 42-47.

Gazali M, Nurjanah, Zamani NP. 2018. Eksplorasi senyawa bioaktif alga cokelat Sargassum sp. Agardh sebagai antioksidan dari Pesisir Barat Aceh. Jurnal Pengolahan Hasil Perikanan Indonesia. 21(1):167-178.

Ghirisan AL, Dragan S, Pop A, Simihaian M, Miclaus V. 2007. Heavy metal removal and neutralization of acid mine waste water-kinetic study. The Canadian Journal of Chemical Engineering. 
85(6): 900-905.

Haryatfrehni R, Dewi, SC, Meilianda A, Rahmawati S, Sari IZR. 2015. Preliminary study the potency of macroalgae in Yogyakarta: extraction and analysis of algal pigments from common Gunungkidul seaweeds. Procedia Chemistry. 14: 373-380.

He J, Chen JP. 2014. A comprehensive review on biosorption of heavy metals by algal biomass: materials, performances, chemistry and modeling simulation tools. Bioresource Technology. 160: 67-78.

Holdt SL, Kraan S. 2011. Bioactive compounds in seaweed: Functional food applications and legislation. Journal of Applied Phycology. 23: 543-597.

Kailola IN, Susanto AB, Prasetyo B, Indriatmoko, Limantara L, Brotosudarmo THP. 2012. Pengaruh beberapa metode pengeringan pada komposisi pigmendan kandungan trans-fukosantin rumput laut cokelat Padina australis. Di dalamProsiding Seminar Karotenoid, Antioksidan dan Flavor; 2012 Mei 1112; Salatiga, Indonesia (ID): Universitas Kristen Satya Wacana:108-118.

Kang YR, Park J, Jung SK, Chang YH. 2018. Synthesis, characterization and functional properties of chlorophylls, pheophytins and Zn-pheophytins. Food Chemistry. 245: 943-950.

Lefsrud M, Kopsell D, Sams C, Wills J, Both AJ. 2008. Dry matter content and stability of carotenoids in kale and spinach during drying. Horticultural Science. 43: 17311736.

Machu L, Misurcova L, Ambrozova JV, Orsavova J, Mlcek J, Sochor J, Jurikova T. 2015. Phenolic content and antioxidant capacity in algal food products. Molecules. 20(1): 1118-1133.

Melendez-Martinez AJ, Escudero-Gilete ML, Vicario IM, Heredia FJ. 2010. Study of the influence of carotenoid structure and individual carotenoids in the qualitative and quantitative attributes of orange juice colour. Food Research International. 43(5): 1289-1296.

Naidu MM, Vedashree M, Satapathy P, Khanum H, Ramsamy R, Hebbar HU.
2016. Effect of drying methods on the quality characteristics of dill (Anethum graveolens) greens. Food Chemistry. 192: 849-856.

Nufus C, Nurjanah, Abdullah A. 2017. Karakteristikrumput laut hijau dari perairan Kepulauan Seribu dan Sekotong Nusa Tenggara Barat sebagai antioksidan. Jurnal Pengolahan Hasil Perikanan Indonesia. 20(3): 620-630.

Nurjanah, Abdullah A, Nufus C. 2018. Karakteristik sediaan garam Ulva lactuca dari perairan Sekotong Nusa Tenggara Barat bagi pasien hipertensi. Jurnal Pengolahan Hasil Perikanan Indonesia. 21(1):109-117.

Pangestuti R, Kim SK. 2011. Biological activities and health benefit effects of natural pigments derived from marine algae. Journal of Functional Foods. 3: 255-266.

Prangdimurti E, Muchtadi D, Astawan M, Zakaria FR. 2006. Aktivitas antioksidan ekstrak daun suji (Pleomele angustifolia NE Brown). Jurnal Teknologi dan Industri Pangan. 17(2): 79-85.

Prangdimurti E, Muchtadi D, Zakaria FR, Astawan M. 2005. The effect of extraction solutions and incubation time on chlorophyll solubility and antioxidant capacity of suji (Pleomele angustifolia NE Brown) leaf extracts. Proceeding of the 9th Asean Food Conference 2005, Jakarta. 8-10 Agustus 2005.

Pumilia G, Cichon MJ, Cooperstone JL, Giuffrida D, Dugo G, Schwartz SJ. 2014. Changes in chlorophylls, chlorophyll degradation products and lutein in pistachio kernels (Pistacia vera L.) during roasting. Food Research International. 65: 193-198.

Ramirez E, Gandul-Rojas B, Romero C, Brenes M, Gallardo-Guerrero L. 2015. Composition of pigments and colour changes in green table olives related to processing type. Food Chemistry. 166: 115-124.

RiceEW, Baird RB, Eaton AD, Clesceri LS. 2012. Standard Method for the Examination of Water and Wastewater. 22th edition. Washington. 3111 b. American Public 
Health Association, American Water Works Association, Water Environment Federation.

Rohani-Ghadikolaei K, Abdulalian E, Ng WK. 2012. Evaluation of the proximate, fatty acid and mineral composition of representative green, brown and red seaweeds from the Persian Gulf of Iran as potential food and feed resources. Journal of Food Science and Technology. 49(6): 774-780.

Sims DA, Gamon JA. 2002. Relationships between leaf pigment content and spectral reflectance across a wide range of species, leaf structures and developmental stages. Remote Sensing of Environment. 81(2-3): 337-354.

Subaryono, Perangiangin R, Suhartono MT, Zakaria FR. 2017. Aktivitas imunomodulator oligosakarida alginat (OSA) yang dihasilkan dari alginat asal Sargassum crassifolium. Jurnal Pengolahan Hasil Perikanan Indonesia. 20(1): 63-73.

Taboada MC, Millan R, Miguez MI. 2012. Nutritional value of the marine algae wakame (Undaria pinnatifida) and nori (Porphhyra purpurea) as food suplements. Journal Applied Phycology.
25: 1271-1276.

Turkmen N, Poyrazoglu ES, Sari F, Sedat Velioglu Y. 2006. Effects of cooking methods on chlorophylls, pheophytins and colour of selected green vegetables. International Journal of Food Science and Technology. 41(3): 281-288.

Yang XT, Zhang ZQ, Joyce D, Huang XM, Xu LY, Pang XQ. 2009. Characterization of chlorophyll degradation in banana and plantain during ripening at high temperature. Food Chemistry. 114(2): 383-390.

Yulianto B, Ario R, Triono A. 2006. Daya serap rumput laut Gracillaria sp. terhadap logam berat tembaga $(\mathrm{Cu})$ sebagai biofilter. Jurnal Kelautan. 11(2): 72-78.

Yong WTL, Chin JYY, Thien VY, Yasir S. 2017. Heavy metal accumulation in field cultured and tissue cultured Kappaphycus alvarezii and Gracilaria changii. International Food Research Journal. 24(3): 970-975.

Zakaria FR, Priosoeryanto BP, Erniati, Sajida. 2017. Karakteristik nori dari campuran rumput laut Ulva lactuca dan Eucheuma cottoni. Jurnal Pascapanen dan Bioteknologi Kelautan dan Perikanan. 12(1):23-30. 